\title{
MODIFICATION OF SOLAR DISTILLATION UNIT TO INCREASE EFFICIENCY IN DRINKING WATER PRODUCTION FROM SALINE WATER
}

\author{
MDHJ Senavirathna ${ }^{1 *}$, KDN Weerasinghe ${ }^{1}$, Mathias Maier $^{2}$, Harald Rosemann $^{2}$ \\ ${ }^{1}$ Department of Agric. Engineering, Faculty of Agriculture, University of Ruhuna, Mapalana, Kamburupitiya \\ ${ }^{2}$ Std werke Karlsruhe, Dexlander str 72, 76127 Karlsruhe, Germany
}

Accepted: $29^{\text {th }}$ September 2009

\begin{abstract}
Solar distillation is one of the appropriate methods which could be used to reduce cost of power in the process of water purification. The commonly used single basin solar distillation systems are not efficient in the process of distillation. Therefore, an experiment was carried out to increase the efficiency of the existing single basin solar distillation unit constructed by the NERD center Sri Lanka by incorporating a $2 \mathrm{~cm}$ thick unsieved river sand layer for heat retention due to its high thermal capacity. It was revealed that, $30 \%$ increment of water distillation could be achieved when sand is incorporated to the solar distillation system even though the internal temperatures of the both systems were not significantly different. Average daily production of the solar distillation system constructed by the NERD center was

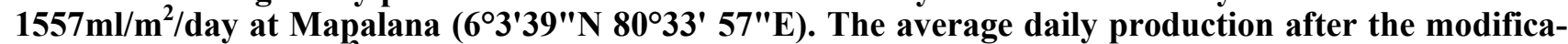
tion was $2017.50 \mathrm{ml} / \mathrm{m}^{2} /$ day at Mapalana. The maximum distillation rate of NERD solar distiller was $2150 \mathrm{ml} / \mathrm{m}^{2} /$ day and $2780 \mathrm{mi} / \mathrm{m}^{2} /$ day for the modified solar distiller during the experiment period. The average inner temperatures of NERD and modified solar distillers were $55.88{ }^{\circ} \mathrm{C}$ and $56.54^{\circ} \mathrm{C}$, respectively when the average ambient temperature was $29.02^{\circ} \mathrm{C}$. Evaporation of more water from the modified solar distiller was the reason for insignificant temperature differences between two solar distillers.
\end{abstract}

Key words: Sand, Solar distillation, Purification

\section{INTRODUCTION}

Solar distillation systems are appropriate low cost methodologies to produce drinking water from salaine water. Solar distillation process removes impurities such as salts and heavy metals as well as microbiological organisms. Most of the people near coastal areas may face with the unavailability of fresh water due to sea water intrusion into groundwater aquifers. It has been reported that due to higher fluoride and other ions, people face health problems in North and North Central provinces of Sri Lanka.

The solar energy has been used for many years in obtaining potable water by distillation from contaminated or brackish supplies (Ihalawela and Careem 2007). As early as 1561, Arabs used solar distillers to obtain drinkable water as well as water based fragrances. In 1861, the French used solar stills to produce Brandy from wine. In 1872, in Las Salinas, Chile' a solar still made of 64 water basins constructed from wood with sloping glass covers was used to supply water to animals working in the local mines. Even the United States military includes solar stills in their survival kits (Speirs 2007).

Apart from the solar distillation, there are various technologies such as Reverse Osmosis (RO), Electrodialysis (ED), Ion-Exchange (IE), Mechanical Filters (MF) etc for water purification
(Avvannavar et al. 2008). However, energy cost and operational and maintenance cost incurred these methodologies increases the production cost of drinking water. (Rodrígueza and Camachob 1999). Production cost without labor charges is around Rs.150/- to Rs. 500/- per cubic meter by Reverse Osmosis and for other methods the cost may be at same range (www.oas.org - 2009).

Use of the solar energy for the distillation of water is one of the appropriate methods to reduce the cost incurred on power when other methodologies are used. The main drawback associated with the solar distillation systems are low distillation efficiency. The solar distiller introduced by the NERD Sri Lanka is a single chamber type and also performing poor distillation efficiency. Therefore, the present experiment was to incorporate a feasible technology to increase the efficiency of the solar distillers. In this experiment the performance efficiency of the $1 \mathrm{~m}^{2}$ size single basin solar distiller manufactured by NERD center was tested, when sand is placed under the black plated corrugated metal sheet that is expected to increase the thermal capacity.

The intensity of solar energy received by the distiller is the single most important parameter affecting the water production (Happer 2007). The daily distilled water output ( $\mathrm{M} \mathrm{e}$ in $\mathrm{kg} / \mathrm{m}^{2} /$ day) is the amount of energy utilized in vaporizing water in the distiller ( $\mathrm{Q}$ e in $\mathrm{J} / \mathrm{m}^{2} /$ day) divided by the latent

\footnotetext{
*Corresponding author: jayasanka@agricc.ruh.ac.lk

Paper presented at the $2^{\text {nd }}$ National Symposium, Faculty of Agriculture, University of Ruhuna
} 
heat of vaporization of water ( $\mathrm{L}$ in $\mathrm{J} / \mathrm{kg}$ ). Solar distiller efficiency (n) is the amount of energy utilized in vaporizing water in the distiller over the amount of incident solar energy on the distiller $\left(Q^{t}\right.$ in $J / \mathrm{m}^{2} /$ day).Thus solar distiller production and efficiencies could be expressed as below (equation 1 and 2). According to the available data the typical efficiency for single basin solar distiller is reaching only to 60\%. (http://www.solaqua.com/ solstilbas.html).

Daily distilled output: $\mathrm{M} \mathrm{e}=\mathrm{Q}$ e $/ \mathrm{L} \quad$ - (1)

Daily distilled efficiency: $n=Q$ e $/ Q$ t - (2)

Therefore, to increase the production of a solar distiller, area of the solar distiller or heat conversion efficiency should be increased. However, increase in efficiency is more viable approach than increase in distiller size owing to several reasons including cost of production, handling and fixing.

\section{MATERIALS AND METHODS}

\section{NERD solar distiller and modification done}

The solar distiller manufactured by NERD center is a single basin type and has 3 main parts, glass sheet, top opened rectangular metal case and black painted corrugated metal sheet. The top side of the rectangular shape metal box $(125 \mathrm{~cm}$ X $85 \mathrm{~cm} \mathrm{X}$ $12 \mathrm{~cm}$ ) was covered with a $3 \mathrm{~mm}$ thick non colored general purpose plain glass sheet and, the corrugated metal plate was fixed within the box. The black painted corrugated metal plate of the solar distiller contains the brackish water which is directly exposed to the solar energy Figure 1. The polluted water is completely enclosed in an air-tight condition inside the solar distiller unit. The incident solar radiation passes through the transparent glass cover which is covering upper side of the distiller and is absorbed by the black painted metal sheet, the absorbed heat is then transferred to the water without significant energy loss. The polluted water get heated and evaporated. The formed vapor on the water surface start moving in an upward direction due to the created driving force (convective currents) and temperature difference between the water and glass

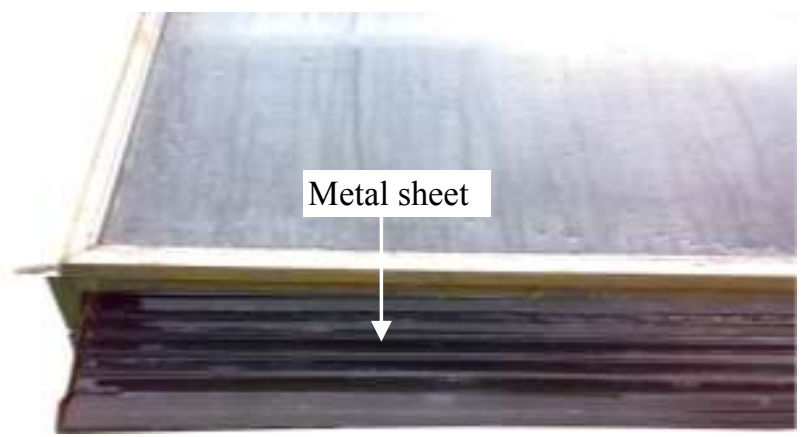

Figure 1: Solar distiller inside view cover which is get in to comparatively low temperature due to heat loss by convection. When the water vapor comes in contact with the glass, the vapor will condense to small-size droplets of freshwater. The condensate starts moving down along the inclined glass cover due to the gravitational force, which will be collected from the collecting channel which is connected to the lower side of the inclined glass sheet (Tarawneh 2007).

\section{Modified Sand Layered Solar distiller}

Same dimensions and materials used for the NERD solar distiller ware used for the construction of modified solar distiller and only the sand basing was the extra component used in the modified distiller. A $2 \mathrm{~cm}$ well dried unsieved river sand layer was placed under the water holding corrugated metal sheet of the solar distiller as illustrated in the Figure 2. A rectangular metal basin made of $1 \mathrm{~mm}$ thick zinc coated metal sheet with depth of $2.2 \mathrm{~cm}$, length of $124.5 \mathrm{~cm}$ and width of $84.5 \mathrm{~cm}$ was used to place sand layer. Approximately $8 \mathrm{~kg}$ of dry sand was evenly applied inside the sand basin. Thereafter, the corrugated metal sheet was placed tightly on sand layer and sealed the edges sheet with the walls of the sand basin using silicon glue.

\section{Meteorological data}

Rainfall data of the experiment period were taken from the meteorological station Faculty of Agriculture, University of Ruhuna, Mapalana. Rainfall data were collected at daily basis. The ambient temperature was taken at hourly interval from 8.00 am to $4.00 \mathrm{pm}$ during the experiment. The average ambient temperature during the experiment was $30.2^{\circ} \mathrm{C}$. The observation period was a dry period with less than $2 \mathrm{~mm}$ average rainfall per day.

\section{Field Validation}

Performance of the modified solar distiller by incorporating the sand layer was tested against the existing distiller in the Science Park, Faculty of Agriculture, University of Ruhuna, Mapalana, Sri Lanka during June - July 2008. Both units were placed at $35^{\circ}$ angle at East-West direction to avoid errors due to the orientation. During the field validation, pipe born water was used and distillers were recharged as it were getting dried. Water distillation rate of the two units was measured at hourly intervals from $8.00 \mathrm{am}-4.00 \mathrm{pm}$, of the day and internal temperatures of both units were also taken at the time of observations.

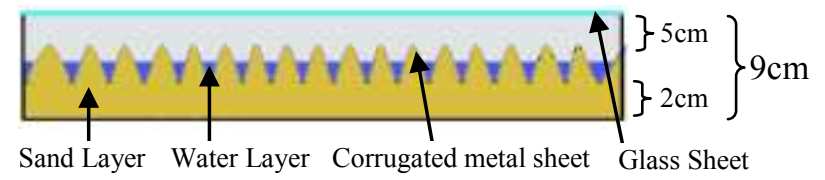

Figure 2: Sand layer beneath the corrugated metal sheet 


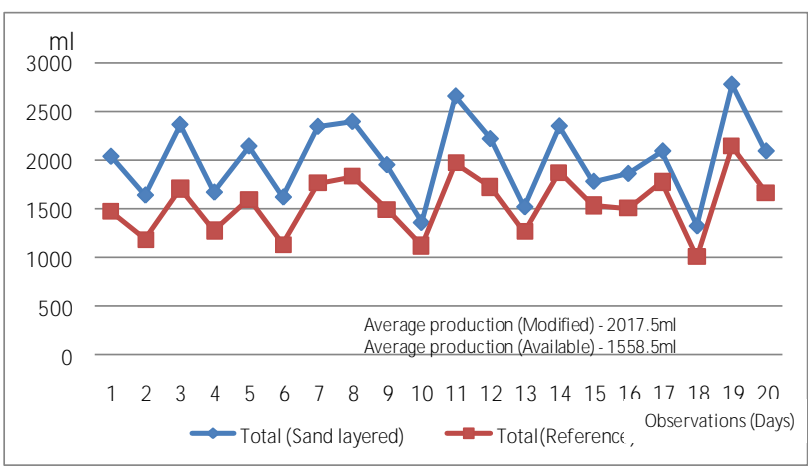

Figure 3: Daily distilled water production. Average production (Modified) - 2017.5ml. Average production (Available) - $1558.5 \mathrm{ml}$

\section{RESULTS AND DISCUSSION}

It was found that the average production rates of water was $2017.5 \mathrm{ml} / \mathrm{m}^{2} /$ day and $1558.5 \mathrm{ml} / \mathrm{m}^{2} /$ day for modified solar distiller and the conventional solar distiller respectively. The average production difference between two solar distillers was $460.5 \mathrm{ml}$ which is a $29.6 \%$ increment in production. Results obtained from the two distiller units are given in the Table 1.

Water distillation patterns have closer similarities for both distillers with a distinct percentage increase in the modified distiller. However, the daily production between two units were significantly differed $(\mathrm{T}$ test $\mathrm{P}$ value $\simeq 0.000)$ and production

Table 1: Water production, temperatures and rainfall statistics

\begin{tabular}{|c|c|c|c|c|c|c|c|}
\hline \multirow[t]{2}{*}{ Date } & \multicolumn{2}{|c|}{$\begin{array}{l}\text { Total water } \\
\text { production } \\
(\mathrm{mm})\end{array}$} & \multirow{2}{*}{$\begin{array}{l}\text { Pro- } \\
\text { duction } \\
\text { differ- } \\
\text { ence } \\
(\%)\end{array}$} & \multicolumn{2}{|c|}{$\begin{array}{l}\text { Internal } \\
\text { temperature } \\
\text { of the distill- }\end{array}$} & \multicolumn{2}{|c|}{$\begin{array}{l}\text { Average Rainfall } \\
\text { Ambient (mm) } \\
\text { temp } \\
\left(C^{0}\right)\end{array}$} \\
\hline & Mod & Ref & & Mod & Ref & & \\
\hline$\overline{08-06-11}$ & 2045 & 1480 & 38.18 & - & - & 38.2 & 0.1 \\
\hline $08-06-12$ & 1650 & 1190 & 38.66 & 50.7 & 49.8 & 31.7 & 0.1 \\
\hline 08-06-13 & 2370 & 1715 & 38.19 & 56 & 55.6 & 32.8 & 5.7 \\
\hline 08-06-14 & 1680 & 1280 & 31.25 & - & - & 29 & 1.3 \\
\hline $08-06-16$ & 2150 & 1605 & 33.96 & - & - & 29.7 & 0.7 \\
\hline 08-06-17 & 1630 & 1140 & 42.98 & - & - & 30.3 & 3.3 \\
\hline 08-06-19 & 2350 & 1770 & 32.77 & 86.4 & 84.4 & 29.3 & 1.3 \\
\hline $08-06-20$ & 2400 & 1840 & 30.43 & 89.6 & 88.3 & 30.7 & 0 \\
\hline $08-06-21$ & 1960 & 1500 & 30.67 & 90.8 & 90.5 & 29.3 & 11.1 \\
\hline $08-06-25$ & 1370 & 1130 & 21.24 & 49.6 & 49.1 & 28.3 & 4.4 \\
\hline $08-06-27$ & 2660 & 1975 & 34.68 & 57.9 & 57 & 27.9 & 0 \\
\hline $08-06-30$ & 2225 & 1730 & 28.61 & 60.2 & 59.9 & 28 & 1.4 \\
\hline 08-07-01 & 1530 & 1270 & 20.47 & 48.9 & 48.6 & 28 & 0 \\
\hline $08-07-02$ & 2355 & 1880 & 25.27 & 63.2 & 62.1 & 28.3 & 0 \\
\hline 08-07-03 & 1790 & 1540 & 16.23 & 60.1 & 58.1 & 27.3 & 0 \\
\hline $08-07-04$ & 1870 & 1510 & 23.84 & 60.8 & 59.8 & 28.9 & 0.3 \\
\hline 08-07-05 & 2100 & 1780 & 17.98 & 62.6 & 62.6 & 29.9 & 2.7 \\
\hline $08-07-07$ & 1335 & 1015 & 31.53 & 49.4 & 49.7 & 31.1 & 3 \\
\hline 08-07-09 & 2780 & 2150 & 29.30 & 60.8 & 60.9 & 33.6 & 0.9 \\
\hline $08-07-10$ & 2100 & 1670 & 25.75 & 59.7 & 58.7 & 32.7 & 3.6 \\
\hline Average & 2017. & 1558.5 & 29.6 & 62.9 & 62.2 & 30.2 & 2.00 \\
\hline
\end{tabular}

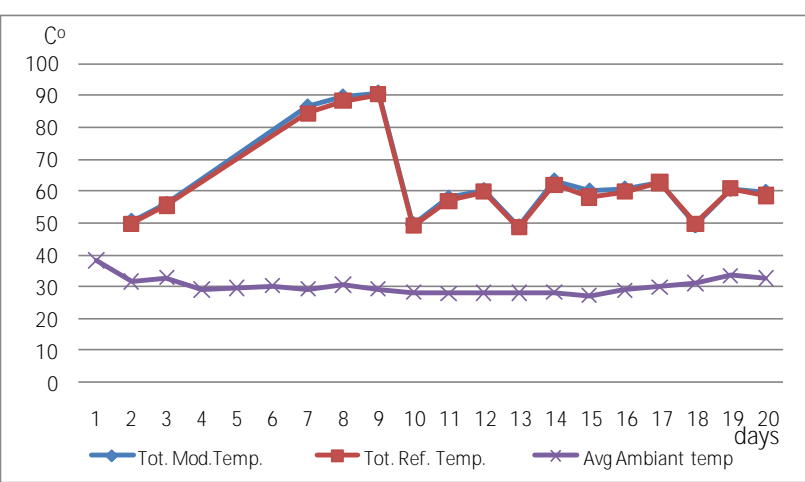

Figure 4: Variation of internal temperatures of distillation units and ambient temperature

difference is increasing with the increase production at an accelerated rate.

The internal temperatures of both units were not sigificantly differed (T test $\mathrm{P}$ value $>0.05$ ) and it has been fluctuated in the range of $48^{\circ} \mathrm{C}$ to $91^{\circ} \mathrm{C}$. It was evident that there is no significat effect on production rate of two distiltion units by difference in internel temperatures of two units withing the 5 percent confidence level. In the other hand, ambient temperature is significantly correlated to the distillation rate of the both distiller units $(\mathrm{P}$ value $<0.05$ ) controlling for internal temperatures. Therefore, it is evident that the ambient temperature is effecting to the production rate of the both distiller units.

\section{CONCLUSION}

The efficiency of the water distillation from the conventional solar distillation unit of $1 \mathrm{~m}^{2}$ could be increased by $29.6 \%$ when $2 \mathrm{~cm}$ unsieved river sand bed is incorporated under the corrugated metal sheet to increase the heat absorption and transferring capacity. The additional heat absorbed by the sand layer from the solar radiation contributes to distill more water from the evaporator which helps to reduce the expansion of the evaporation surface to increase production.

The modified solar distillation unit with $1 \mathrm{~m}^{2}$ area produced about $2100 \mathrm{ml}$ of water per day under the prevailing climatic conditions of Mapalana during June - July 2008.

\section{REFERENCES}

Avvannavar SM, Manil M and Kumar N 2008 An Integrated Assessment of the Suitability of Domestic Solar Still as a Viable Safe Water Technology for India, "Environmental Engineering and Management Journal", Vol.7, No.6, pp 668 
Happer GDJ 2007 Solar energy projects for the Evil Genius, Mc Grow Hill Coperations, pp 59

Ihalawela PHCA and Careem MA 2007 A Cheap Automatic Solar Water Distiller, "Proceedings of the Technical Sessions 23", pp 41-45. Institute of Physics, Sri Lanka

Rodrígueza LG and Camachob CG 1999 Preliminary design and cost analysis of a solar distillation system, "Solar Energy". pp 109-114 Departamento Física Fundamental Experimental, Universidad de La Laguna, 38205 La Laguna (Tenerife), Canary Islands, Spain

Speirs R 2007 Solar Distillers. http://www. gomestic.com/Emergency-Preparation/SolarDistillers.32567 12/10/2008
Suleiman M and Tarawneh K Effect of Water Depth on the Performance Evaluation of Solar Still, 2007 "Jordan Journal of Mechanical and Industrial Engineering" Volume 1, Number 1, pp25

http://www.oas.org/dsd/publications/Unit/oea59e/ ch20.htm 22/08/2009 Desalination by reverse osmosis

http://www.solaqua.com/solstilbas.html 8/8/2008 Solar Still Basics. 